\title{
The utilities of Citrus tissue culture
}

\author{
Firoozeh Chamandoosti
}

Iranian Research Institute of Plant Protection, Agricultural Research, Education and Extension Organization (AREEO), Tehran, Iran

PhD of Cellular and Developmental Biology, Assistant Professor of Iranian Research Institute of Plant Protection Department of Plant Diseases

\begin{abstract}
Citrus is the third most important fruit crop in the world after apple and bananas, and the total area cultivated with the various Citrus cultivar covers over 7.2 million hectares, yielding total annual production of approximately 100 million metric tons of fruit. The genus Citrus possesses several undesirable characteristic including salt and cold sensitivity they are also susceptible to diseases caused by fungi, bacteria and viruses. Despit substantial genetic diversity and interspecific fertility, the genus Citrus includes some of the most difficult species to breeding. For example, most species are highly heterozygous and produce progeny that segregate widely for many characters when crosses are made. The juvenile periods are often very long, self- and cross-incompatibility and pollen and/or ovule sterility are relatively common, and the presence of adventitious somatic embryos in the nucellus of developing ovules of the most of Citrus greatly limits hybrid production. Genetic transformation is an alternative to overcome these difficulties. For successful transformation, regeneration of whole plants from the transformed cells is a prerequisite. On the other hand production of virus - free plants, development of new cultivars, and production of seedless fruit, production of flavonoid, micropropagation, germplasm conservation and cryopreservation are the other utilities of in vitro culture of Citrus.
\end{abstract}

Keywords-Citrus, Improvement, Tissue culture.

\section{INTRODUCTION}

Tissue culture is the in vitro aseptic culture of cells, tissues, organs or whole plant under controlled nutritional and environmental conditions (Thorpe 2007) often to produce the clones of plants. It is clear that in vitro culture is an essential component of plant - biotechnology, offers innovative approaches in several research areas (Annarita and Laura 2012). The importance of plant cell, tissue and organ culture is more cleared when it includes in major fruit crop in vitro culture regarding to micropropagation, the induction of somatic embryogenesis, the improving of methodologies through the analysis of medium components, and the use of additives to increase the frequency of regeneration and the production of the in vitro cultures for the important species such as species belong to genus Citrus. The genus Citrus is cultured in more than 100 countries making it one of the most important commercial fruit crops in terms of economic value and human nutrition (Barlass and Skene 1986). Citrus is the most important fruit crop in the world and is produced in all five continents and it is often regarded as golden fruit or queen of all fruits (Nito 1996).

Despite substantial genetic diversity and interspecific fertility, the genus Citrus includes some of the most difficult species to breed (Gmitter et al., 1992 \& Perez - Molphe - Balch and Ochoa - Aljeo 1998). This is due to several obstacles for conventional breeding. For example, most species are highly heterozygous and produce progeny that segregate widely for many characters when crosses are made. The juvenile periods are often very long, self - and cross - incompatibility and pollen and/or ovule sterility are relatively common, and the presence of adventitious somatic embryos in the nucellus of developing ovules of the most of Citrus greatly limits hybrid production (Perez - Molphe - Balch and Ochoa - Aljeo 1998 \& Moore et al., 1993). Genetic transformation is an alternative to overcome these difficulties. For successful transformation, regeneration of whole plants from the transformed cells is a prerequisite (Duan et al., 2007). In this review some of the most important utilities of Citrus tissue culture that are based on result of different experiments in this field were explained.

\section{THE CITRUS GENIUS NEED TO IMPROVEMENT}

Citrus belongs to family Rutaceae having 150 genera and 15,000 species and it is distributed mostly in tropical and temperate region of the planet (Ladania 2008). A number of major genera of family Rutaceae are Citrus, Murraya, Zanthoxylum and Ruta etc. (Perveen and Qaiser 2005). As mentioned earlier Citrus has high dietary value and is a prosperous source of vitamin $\mathrm{C}$ in combination with macromolecules such as amino acids, organic acids and sugar as well as minerals comparable to magnesium and calcium in sufficient quantity (Niaz et al., 2004). The genus Citrus possesses several undesirable characteristics including salt and cold sensitivity (Garcia - Agustin and Primo - Millo 1995 \& Van Le et al., 1999) they are also susceptible to diseases caused by fungi, bacteria and viruses, such as Citrus exocortis viroid (CEV), 
Citrus infectious variegation virus (CIVV), Citrus cachexia viroid (CCaV) and Citrus tristeza closterovirus (CTV) (Van Le et al., 1999 \& Greno et al., 1988). These biotic and abiotis stresses cause to low productivity. So Citrus genius has a great need to improvement.

\section{TISSUE CULTURE IS A BASIC PREREQUISTIC FOR GENE TRANSFER IN CITRUS}

In recent years, there has been a major thrust in Citrus improvement as competition from international Citrus markets, disease, and pest pressure and other abiotic and biotic stress conditions stimulate worldwide interest (Grosser et al., 2000 \& Dutt and Grosser 2010).

Genetic transformation of Citrus is a valuable technique for Citrus improvement due to difficulties of conventional Citrus breeding. Recently, Citrus improvement using genetic transformation is being used frequently as increasing competition in international markets and disease pressure have stimulated worldwide interest in Citrus improvement (Grosser et al., 2000). In Citrus, gene transformation is carried out by three different techniques i.e., particle bombardment (Jia - Long et al., 1996). protoplast transformation (Fleming et al., 2000) and Agrobacterium (Nuria et al., 2012; De Oliveria 2009; Yang and Hu 2011 \& Cervera et al., 1998).

Currently, Citrus canker and huanglongbing (HLB) are the two major diseases threatening the Citrus industry. Canker results in leaf - spotting and blemishing on the surface of the fruit, often resulting in defoliation, shoot dieback, and fruit drop. HLB affects all cultivated Citrus varieties and causes a rapid decline of trees and the production of unmarketable fruit. Both these diseases are caused by non - indigenous bacterial pathogens and cause substantial economic losses. Incorporation of gene(s) via genetic engineering can potentially confer resistance in susceptible cultivars, while maintaining the varietal fidelity. Transgenic Citrus plants have been obtained by direct DNA trasfer into protoplasts (Vardi et al., 1990) co - cultivation of internode or epicotyl segments with Agrobacterium (Moore et al., 1992; Pena et al., 1995a \& Gutierrez et al., 1997). And particle bombardment of nucellar embryogenic cell suspentions (Yao et al., 1996). At persent, the most widely used method of gene trasfer in Citrus is the Agrobacterium - mediated transformation of epicotyl segments with $1 \mathrm{~cm}$ of length. Using this system, transgenic plants of Citrus sinensis (Pena et al., 1995a \& Bond and Roose 1998), Citrus aurantifolia (Gutierrez et al., 1997), Citrus aurantium (Pena et al., 1997; Citrus paradasi (Luth and Moore 1996; Citrus sinensis x Poncirus trifolia (Moore et al., 1992 \& Pena et al., 1995a) and Citrus trifoliata (Kaneyoshi et al., 1994) have been obtained. However, this method is not suitable for the transformation of any seedless cultivar. Also, special cultivars in themandarin group remain robust to transform using this method (Dutt and Grosser 2010; Dutt et al., 2010 \& Khawale et al., 2006).

Due to the limitations of this method it seems that in order to carry out successful gene transformation studies in Citrus, optimized in vitro regeneration protocol is needed. Researchers should optimize efficient regeneration protocol before starting transformation studies. There are also many efficient regeneration protocols published in different Citrus species. In Citrus, callus cultures have been established in species such as Citrus grandis L. Osb. Citrus auruntifolia (Christm.) Swingle. Citrus medica L. Citrus sinensis L. Osb. Citrus madurensis L. Citrus paradisi Macf. Citrus reticulata Blanco and Citrus limon (Sabharwal 1963; Murashige and Tucker 1969; Grinblat 1972; Chaturvedi and Mitra 1975; Moore 1985; Duran-Vila et al., 1989; Gill 1992 \& Gill et. al., 1994). Responses to different culture media are often genotype - specific. So the more optimization of tissue culture techniques is essential for gene transfer in Citrus.

\section{TISSUE CULTURE (MICROPROPAGATION) IS A POWERFUL TOOLS FOR PRODUCTION OF VIRUS - FREE CITRUS SPECIES}

Micropropagation is an important asexual method that can be used for the production of virus - free rootstock plants (Roistacher et al., 1976). As mentioned earlier Citrus, due to pedoclimatic conditions, often suffers from abiotic stresses such as salinity, drought and iron deficiency induced chlorosis; nevertheless, a major constraint for its cultivation is represented by graft - transmissible agents (viruses, virus - like, viroids, prokaryotes), that may cause considerable losses in crop yield and quality of plants and plant products. These agents may often remain symptomless, thus representing a special risk in their spread over long distances through Citrus infected propagating material. The worldwide movement of graft transmissible pathogens and relative vectors, along with the Citrus material, has increased in the last years due to the strong globalization and the lack of adequate quarantine measures. Once they invade a cultivated area, the most severe pathogens can be rapidly spread by insect vectors and their control becomes even more difficult (Carimi et al., 2013).

Virus and viroid's have been recognised as serious problem limiting the vigour, yield, quantity and quality. Severe infections have resulted in the exclusion of some cultivars from commercial usage, reported that viral diseases are major threats affecting Citrus industry (Vishwanath and Narayan 2015). The diseases are graft - transmissible through grafting infected 
bud sticks (Santos et al., 1984). Hence, rising of disease - free foundation plants is imperative to provide certified bud sticks to the growers and to encourage the planting of grafts instead of seedlings (Mukhopadhyay et al., 1997).

The elimination of viruses, viroids, and phytoplasmas from infecte initial (mother) propagation material is a prerequisite for the production of healthy, vegetatively propagated crop material. Methods used are thermotherapy, meristem tissue culture, in vitro micrografting, in vitro chemotherapy, and cryotherapy of shoot tips, followed by shoot - tip tissue culture or in vitro micrografting (Christina 2015).

As all of us know meristem tissue culture, in vitro micrografting and cryotherapy of shoot tips, followed by shoot - tip tissue culture or in vitro micrografting are the basic tissue culture methods for virus elimination in plants. But we have to keep in mind that all metdods arenot suitable for all plants. For example meristem culture that is used for the elimination of viruses and related pathogens from a large number of vegetatively propagated plants and it is the main method used in plant virus elimination programs for some plants, such as Citrus, stone fruits, and other woody species, meristem cultures are not successful (George 1993b \& Navarro 1988). In these cases, the meristem tip is grafted onto a virus free rootstock. The micrografting technique was first used for the elimination of viruses and viroids in Citrus by Navarro et al., 1976. Several scientists thereafter adopted this method to produce virus free plant material in Citrus Kapari -Isaia et al., 2002; 2007; Mukhopadhyay et al., 1997; Navarro Civerolo Juarez and Garney 1991; Navarro Juarez and Pina 2001; Navarro et al., 1975; Singh 2001). In fact the use of tissue culture methods for Citrus crop species has already had practical benefits. Most notable among these are techniques for obtaining virus - free and mycoplasma - free stocks using in vitro grafting of apical meristems from infected plants onto decapitated seedlings (Navaro et al., 1975).

The issue that has been considered in recent years is that growing nucellar seedlings was the only method available for producing disease free Citrus cultivars from clones infected with virus or other grafttransmissible pathogens. The primary disadvantage of producing Citrus budlines through nucellar embryony is the phenomenon of juvenility. Young nucellar seedlings exhibit excessive thorniness, vigorous and up - right habit of growth slowness to fruit, alternate bearing in early years and physical differences in fruit characteristics, which are often detrimental in marketing the fruit. These characteristics may persist for many years and over many budded generations. Nucellar budlines usually produce higher yields of fruit than their parental clones over a period of $8-10$ years or more (Cameron et al., 1968; Nauer et al., 1983). The portion of this higher yield that can be attributed to elimination of virus and virus - like pathogens in the parental bud - line has not been determined. Variations among Citrus nucellar budlines and differences, other than juvenility, from the parental budline have been reported (Frost et al., 1957; Nauer et al., 1983) in numbers indicating that genetic variants may occur more often during production of nucellar bud - lines than occur during standard nursery trees production by bud propagation. Therefore, a method to recover Citrus plants free of all virus and virus - like diseases and without juvenile characters was needed. The first attempts in this direction were made by shoot -tip culture in vitro, a technique widely used to recover healthy herbaceous plants. However, attempts to develop Citrus plants from shoot - tips failed (Edriss et al., 1984).

Constraints of this method, the use of alternative methods such as somatic embryogenesis can be useful. Somatic embryogenesis is a developmental process where a plant somatic cell can dedifferentiate to a totipotent embryonic stem cell that has the ability to give rise to an embryo under appropriate conditions. This new embryo can further develop into a whole plant. In woody plants, somatic embryogenesis plays a critical role in clonal propagation and is a powerful tool for synthetic seed production, germplasm conservation, and cryopreservation (Yuan et al., 2016). Also somatic embryogenesis can be used to eliminate many virus diseases (Bitters et al., 1970; D'Onghia et al., 1997; D'Onghia et al., 2001), the plant material obtained by somatic embryos regenerated in vitro can be used to establish healthy Citrus stocks. On the other hand while other plant micro - organisms are in many cases controlled by therapeutic treatments directly performed in the field, graft transmissible agents cannot be eliminated by these means because of the peculiarity of their replication cycle. Pro - active strategies, which primarily rely on lower disease incidence and restrain virus dissemination, can prevent the introduction of these agents into new plantings and new areas; this is less hard and expensive than eliminating them once they are already present. Within this context, strict phytosanitary regulations and certification programmes for the production of 'healthy' Citrus nursery plants are amongst the most efficient preventive strategies (Carimi et al., 2013).

In Citrus, the production of embryogenic callus lines was reported from excised nucelli (Rangan et al., 1968), abortive ovules (Bitters et al.,1970), unfertilized ovules (Button and Bornman, 1971), undeveloped ovules (Starrantino and Russo, 1980), juice vesicles (Nito and Iwamasa, 1990), anthers (Hidaka et al ., 1981), styles and stigmas (Carimi et al., 1995) as well as from leaves, epicotyls, cotyledons and root segments (Gill et al., 1995). The embryogenic potential of Citrus varied with genotype and type of explant. in vitro culture of ovules from ovaries and immature fruits was initially used to obtain 
virus - free nucellar plants from polyembryonic Citrus cultivars (Bitters et al., 1970; Navarro et al., 1979). Somatic embryos, embryogenic callus and cell cultures recovered from in vitro cultured ovules have also been used to develop cryopreservation strategies for germplasm conservation (Kobayashi et al., 1990; Marin et al., 1993; Engelmann et al., 1994; Sakai et al., 1990 and 1991; Duran - Vila 1995) and protoplast technologies (Vardi and Galun, 1989; Grosser and Gmitter, 1990 a and b; Gimitter et al., 1992). Recent studies have indicated the embryogenic potential of somatic tissues which are neither nucellar nor ovular in origin. Nito and Iwamasa 1990 obtained eight somatic embryos from cultures derived from Satsuma juice vesicles. Carimi et al., 1995 induced formation of embryogenic cultures from styles of different species of Citrus. Gill et al ., 1995 obtained somatic embryos from leaf, epicotyl, cotyledon and root segments of in vitro grown nucellar seedling of $C$. reticulata Blanco.

\section{OTHER UTILITIES OF CITRUS TISSUE CULTURE}

\subsection{Development of new cultivars}

Citrus propagation by conventional means is restricted to particular season and availability of plant material. It doesn't guarantee trueness of cultivars and mass production of certified Citrus plants throughout the year. Plant tissue culture has emerged as a powerful tool for propagation and improvement of many woody plant species including Citrus. Citrus also stands among difficult to root crops and micropropagation offers rapid propagation of such crops in limited space and time under controlled conditions throughout the year (Usman 2005). In vitro culture further eliminates diseases (Grosser and Chandler 2000) provides scope for the development of new cultivars through somaclonal variation (Hammschlag et al., 1995) and somatic hybridization ( Al - Bahrany 2002; Grosser et al., 1996; Louzada et al., 1996; Mendes - da - Gloria 2000; Ollitrault et al., 1996; Ollitrault et al., 2000 \& Paudyal and Haq 2000) that have improved Citrus rootstock resistance against nematode infestation and other pests as well (Bouquet et al., 2003; Grosser et al., 1998; Guo and Deny 1998 \& Guo and Deny 2001). Industry, the micropropagation of Citrus has always aroused great interest among scientists. There is a growing demand to develop new varieties of plants resistant to pathogens and adverse environmental conditions and characterized by high quality of fruits (Yaacob et al. 2014). Traditional techniques for creating new species are not effective in the case of Citrus (lemons) due to the problems that have already been mentioned such as physiological barriers associated with sexual reproduction such as heterozygosity and polyembriony (Tusa et al. 1990, Carimi et al. 1994, Savita et al. 2010, Benabdesselam et al. 2011, Lombardo et al. 2011).

Citrus (Lemons) plantations face a number of problems such as pests, slow growth, susceptibility to disease, sensitivity to low temperatures, and substantial losses during storage (Mukhtar et al. 2005a, b, Savita et. al. 2010, Sarma et al. 2011). In vitro culture is a technique that can solve these problems. In addition, this technique can also produce crops on a relatively large scale in comparison with traditional plant breeding. Furthermore, in vitro cultures eliminate infections and can be faster than traditional plant cultures (Savita et al. 2011, Singh and Kaur 2011).

Development of new cultivares by tissue culture that mentioned above is due to a phenomenon called somaclonal variation. The term somaclonal variation was coined by Larkin and scowcraft 1981 to define genetic variation present in regenerated plants that is uncovered or induced by a tissue culture process. Somaclonal variation has been reported in a wide range of traits including plant height, overall growth habit, flower, fruit and leaf morphology, juvelinity, maturity date, diseases resistance, yield and biochemical charactristics. However most reports generally deal with either solanaceous or cearal crops but little information has been reported in woody prenial fruit crops (Grosser et al., 1997).

\subsection{Production of seedless Citrus fruit}

In recent years, there has been a shift in the world Citrus market towards seedless Citrus fruits and considerable energy has been devoted towards their production. The seedless trait in Citrus is related to male or female gametophyte sterility, self incompatibility, or early embryo abortion (Reforgiato Recupero et al. 2005), and several methods exist for the production of seedless Citrus of which mutation breeding, somaclonal variation and triploid breeding are the most important. In Citrus, triploid seedless cultivars are obtained by breeding between elite monoembryonic diploid cultivars as female parent with tetraploid cultivars as pollen parent (Esen and Soost 1973). Sterility in such fruits is caused due to the odd number of chromosomes that are unable to undergo successful meiotic pairing to produce chromosomally balanced gametes (Reforgiato Recupero et al., 2005).

Colchicine is an alkaloid obtained from the meadow saffron (Colchicum autumnale L.). This alkaloid inhibits mitosis by hampering the development of the nuclear spindle (Blakeslee and Avery 1937) and is most commonly used to obtain tetraploid plants artificially (Notsuka et al. 2000). In Citrus, tetraploidy has been induced by treatment of axillary buds with 
colchicine, as was done with the cultivars Ellendale and Clementine. The treated buds upon grafting on rootstock produced several tetraploid plants (Oiyama 1992). However, a disadvantage of using axillary buds in colchicine experiments is that most of the recovered plants end up being unstable chimeras and do not have applications in a breeding program (Barrett 1974; Jaskani et al., 1996). This is due to the use of multicellular tissue as a source of explants for colchicine treatment. Using such tissues usually result in production of a large proportion of chimeric tetraploids (Kadota and Niimi 2002). Non c-himeric autotetraploid Citrus plants have been obtained from in vitro colchicine experiments via embryogenesis of underdeveloped ovules from immature Citrus fruits (Gmitter and Ling 1991; Gmitter et al. 1991).

\subsection{Production of flavonoid}

Citrus and Citrus peels contain common flavonoids, such as hesperidin, naringin, neohesperidin, narirutin, eriocitrin, didymin and rutin among others (Benavente - Garcia et al., 2007; Tripoli et al., 2007 \& Gattuso et al., 2007). A number of studies have demonstrated the biological properties of these Citrus flavonoids including anti - carcinogenic, anti-oxidant and anti-inflammatory properties that promote and benefit human health (Tripoli et al., 2007; Gattuso et al., 2007; Lopez Lazaro et al., 2002 \& Wang et al., 2014) . In addition to Citrus flavonoids, Citrus peels are also the sole and rich source of polymethoxylated flavonoids, which were found to exert many biological properties, particularly anti-cancer and anti inflammatory activity (Li et al., 2009; Gosslau et al., 2014; Li et al., 2014 \& Li et al., 2014). Recent studies have also demonstrated potent anticarcinogenic and anti - inflammatory efficacy of 5-demethylated polymethoxyflavones in single molecules (Li et al., 2014; Ma et al ., 2014 \& Lai et al., 2007) or in multiple 5-demethylated polymethoxyflavones (Lai et al., 2011). The natural content of 5 -demethylated polymethoxy flavones in Citrus peels is low in percentage, but it has been confirmed that they have more potent biological activity than their non-demethylated counterparts, such as anticancer activity (Lai et al., 2014; Lai et al., 2007 \& Lai et al., 2011).

In essence, there are three subclasses of Citrus flavonoids exiting abundantly in Citrus peels, namely, polyhydroxy flavonoids, polymethoxy flavonoids and mixed substituted flavonoids with both hydroxyl and methoxyl groups, particularly 5 - demethylated polymethoxyflavnoids. These flavonoids have demonstrated effective anti - cancer property both in vitro and in vivo, either in a form of individual compounds or in a mixture of Citrus flavonoids. The anti - cancer study of these flavonoids has progressed well in recent years owing albeit in the initial steps to the modern chemical analysis and isolation and the biological activity testing. However, with the exception of nobiletin, the relationships between each individual flavonoid in Citrus peels and its bioactivity such as anti - carcinogenesis remain untouched to some extent. Relationships among the naturally proportioned flavonoidsin Citrus peels and their biological activities are even more complex and unexplored.

Biotechnology uses techniques and processes that involve living organisms to obtain specific products and/or modifications that increase the production of chemical substances of interest in less time and less capital investment (Davies and Deroles 2014). Secondary metabolites such as Citrus flavonoids that are found in plants are generally produced in low concentrations compared with primary metabolites. Therefore, different strategies, including in vitro culture systems, have been extensively studied to increase the production of secondary metabolites in plants (Smetanska 2008; Muranaka and Saito 2010 \& Gill et al., 2013). In vitro cell cultures represent an interesting alternative because secondary metabolites of interest are obtained in a controlled environment that is not influenced by changes in climate or soil conditions (Goncalves and Romano 2013 \& Collin 2001). Plants that are grown in their natural habitat generally have varying concentrations of compounds of interest, depending on the particular crop season (Salmore and Hunter 2001; Puricelli et al., 2002 \& Ralphs and Gardner 2001). Moreover, their exploitation in their natural environment can cause gradual genetic erosion (Sidhu and Bel 1996). Also callus cultures and cells in suspension have been used to study the biosynthesis of economically important secondary metabolites enabling the propagation of cell lineages that contain alterations in biosynthetic capabilities. he production of different compounds in plants is generally mediated by environmental factors that vary according to physiological conditions and seasonal variations (Gill et al., 2013). Thus, cell cultures ensure controlled conditions that circumvent environmental changes.

\subsection{Micropropagation, Germplasm conservation and Cryopreservation}

Citrus trees are propagated both by seed and by vegetative means. There is huge demand of planting material. Non availability of scientifically propagated planting material from elite clones for plantation are the main constraints in Citrus cultivation. In recent years tissue culture techniques (micropropagation) are increasingly used for rapid clonal propagation of several economic plants, restoration of vigour and yield due to infection and preservation of germplasm. Hence 
micropropagation is a very useful tool for a production of large number of planting materials. Besides this technique is also useful for saving the Citrus species which are facing extinction (singh 2002).

Conservation of Citrus germplasm in the field requires great space, labour and costs the risk of damage by natural calamities and pathogen infection that may be always incurred. Therefore, in vitro conservation can easily overcome these difficulties, and ensuring the maintenance of healthy Citrus germplasm. Moreover, for several Citrus species, in vitro culture may play a major role as a conservation strategy or even be the only option available. For an efficient in vitro conservation of healthy germplasm, we need suitable protocols of plant regeneration. Fortunately, there exist many reports on organogenesis from different types of explants of Citrus and Citrus rootstocks. The morphogenic responses of Citrus cultured in vitro are influenced by the genotype, the explant type and the culture medium. Explants include shoot tips (Barlass and Skene 1986), stem sections (Grinblat 1972; Chaturvedi and Mitra 1974 ; Raj Bhansali and Arya 1979 \& Barlass and Skene 1982), root sections (Sauton et al., 1982; Burger and Hackett 1986; Sim et al., 1989 \& Bhat et al., 1992) leaf sections (Chaturvedi and Mitra 1974 \& Hu and Kong 1987), stem internodes (Duran - Vila and Navarro 1989), epicotyl segments (Edriss and Burger 1984) and transverse thin cell layer (tTCL) explants excised from stem options (Van Le et al., 1999). The regeneration of adventitious shoots has been obtained either directly from the explant or from an intermediate callus phase.

Also as noted above traditionally, Citrus germplasm is preserved in clonal orchards, where it is susceptible to pests, diseases and climatic catastrophes (Duran - Vila, 1995). Cryopreservation of embryogenic calli at ultra - low temperatures $\left(-196{ }^{\circ} \mathrm{C}\right)$ in liquid nitrogen (LN2) is an excellent mean to overcome the challenges inherent to maintaining embryogenic materials and to provide long - term conservation of valuable embryogenic lines (Gonzales - Arnao et al., 2008). There are many studies on Citrus cryopreservation using very different materials. Efficient vitrification and dehydrationbased cooling procedures have been reported for various Citrus organs and tissues, including shoot tips (Wang and Deng, 2004), seeds (Kaya et al., 2016), embryonic axes (Cho et al., 2002), somatic embryos (Marin and Duran - Vila, 1988), ovules (Gonzales - Arnao et al., 2003), embryogenic calli (Perez et al., 1997 \& Olivares - Fuster et al., 2000) and nucellar cells (Sakai et al., 1990). And ultimately, as we all know, the success of any of these methods requires the establishment of appropriate tissue culture systems.

\section{CONCLUSION}

Like the vast majority of genera and species of plants, especially economically important genera and species, different species of Citrus genius need to improvement. Citrus improvement by conventional methods due to difficulties such as has limitations that all of them solve by modern methods of biotechnology or in other words transformation. Low plant regeneration frequencies especially for many of the economically important Citrus species is the most important difficult within this almost new and advanced method. So the progression of tissue culture methods leads to solving these problems.

\section{REFERENCES}

[1] Al - Bahrany A.M. 2002. Effect of phytohormones on in vitro shoot multiplication and rooting of lime (Citrus aurantifolia Swing.). Scientia Horticulturae. 95: 285 - 295

[2] Annarita L. and Laura M.R.R. 2012. Recent advance in plant in vitro culture. Page 8. http://dx.doi.org/10.5772/52760. Edited by Annarita Leva and Laura M. R. Rinaldi

[3] Barrett H.C. 1974. Colchicine - induced polyploidy in Citrus. Bot Gaz 135:29 - 34

[4] Barlass M. and Skene K.G.M. 1982. In vitro plantlet formation from Citrus species and hybrids. Scientia Horticulturae. 17: 333 341

[5] Barlass M and Skene K.G.M. 1986. Citrns. In Bajaj Y.P.S. (Ed) Biotechnology in Agricultureand Forestry 1. Trees I, SpringerVerlag, Heidelberg. pages $207-219$

[6] Benabdesselam F.M. Khettal B. Bedjou F. 2011. Micropropagation of Algerian juvenile rootstocks Citrus species. Lief Sciences Leaflets. 18:707 - 717

[7] Benavente - Garcia O. Castillo J. Alcaraz M. 2007. Beneficial action of Citrus flavonoids on multiple cancer - related biological pathways. Current Cancer Drug Targets. 7: $795-809$

[8] Bhat S.R. Chitralekha P. and Chandler K.P.S. 1992. Regeneration of plants from long-term root culture of lime, Citrus aurantifolia (Christm. Swing). Plant Cell Tissue and Organ . Culture. 29: $19-25$

[9] Bitters W.P. Murashige T. Rangan T.S. and Nauer E. 1970. Investigations on established virus free plants through tissue culture. California Citrus Nursery Society. 9: 27 - 30

[10] Blakeslee F.A. Avery A.G. 1937. Methods of inducing doubling of chromosome in plants.journal of Heredity. 25:80 - 108

[11] Bond J.E. and roose M. L. 1998. Agrobacterium - mediated transformation of commercially important Citrus cultivar Washington navel orange. Planr Cell Reports. 18: 229 - 234 
[12] Bouquet A. Mark G. Pistanga D. Torregrosa L. 2003. Transfer of grape fan leaf virus coat protein gene through hybridization with Xiphinema index resistant genotypes to obtain rootstocks resistant to virus spread. Acta Hort. 603: 325 - 324

[13] Burger D.W. and Hackett W.P. 1986. Gradients of adventitious bud formation on excised epicotyl and root sections of Citrus. Plant Science. 43: $229-232$

[14] Button J. and Bornman C. H. 1971. Development of nucellar plants from unpollinated and unfertilized ovules of the Washington navel orange in vitro. South African Journal of Botany. 37: 127 - 134

[15] Cameron J.W. and Frost H.B. 1968. Genetics, breeding and nucellar embryony. In: Reuther et al. (eds.), The Citrus Industry. University of California Division Agriculture Science, Berkeley. 2(5): 325 - 370

[16] Carimi F. De Pasquale F. Crescimanno F.G. 1994. Somatic embryogenesis from styles of lemon (Citrus limon L. Burm). Plant Cell Tissue and. Organ Culture. 37, $209-211$

[17] Carimi F. De pasquale F. and Crescimanno F.G. 1995. Somatic embryogenesis in Citrus from styles culture. Plant Science. 105: 81 86

[18] Carimi F. D'Onghia A.M. Carra A. and Djelouah K. 2013. Somatic Embryogenesis, Genetic Fidelity of Somatic Embryo Derived Plantlets and Virus Elimination in Citrus. Somatic embryogenesis and gene expression. $124-145$

[19] Cervera M. Pina J. Juarez J. Navarro A. Navarro L. Pena L. 1998. Agrobacterium mediate transformation of citrange: Factors affecting transformation and regeneration. Plant Cell Reports. 1998 18(3):271 - 278

[20] Chaturvedi H.C. and Mitra G.C. 1974. Clonal propagation of Citrus from somatic callus cultures. Horticultural Science.: 118 - 120 Chaturvedi H.C. and Mitra G.C. 1975. A shift in morphogenetic pattern in Citrus callus tissue during prolonged culture. Annals of Botany. 39: $683-687$

[21] Cho E.G. Hor Y.L. Kim H.H. Rao V.R. Engelmann F. 2002. Cryopreservation of Citrus madurensis embryonic axesby encapsulation - dehydration. Cryo Letters. 23: 325 - 332

[22] Christina V. Varvara I. M. Theodora K.I. Isaia. 2015. Principles for supplying virus - tested material. Advances in Virus Research. 91: $1-32$

[23] Collin H.A. 2001. Secondary product formation in plant tissue cultures. Plant Growth Regulators. 34: 119 - 134

[24] Davies K.M. Deroles S.C. 2014. Prospects for the use of plant cell cultures in food biotechnology. Current Opinion in Biotechnology. 26: $133-140$

[25] De Oliveira M. 2009. High - efficiency Agrobacterium-mediated transformation of Citrus via sonication and vacuum infiltration. Plant Cell Reports. 28(3):387 - 395

[26] D’Onghia A. M. De pasquale F. Carimi F. Savino V. and Crescimanno F.G. 1997. Somatic embryogenesis from style culture as a possible means for virus elimination in Citrus. Journal of Phytopathology. 145: 77 - 79

[27] D’Onghia A.M. Savino V. Kyriakou A.P. Yilmaz M.A. Baloglu S. Stamo B. Khoury W. Boubker J. Drossopoulou J. Abdel-Salam A.M. 1998. Proposal of a scheme for the production maintenance and utilization of Citrus certified propagative material in the Mediterranean. Proceeding of the Mediterranean Network on Certification of Citrus. Options Mediterraneennes Serie B 21 CIHEAM Publications. Pages $135-152$

[28] D’Onghia A. M. Carimi F. De pasquale F.Djelouah K and Martelli G.P. 2001. Elimination of Citrus psorosis virus by somatic embryogenesis from stigma and style cultures. Plant Pathology 50: 266 - 269

[29] Duan Y.X. Liu X. Fan J. Li D.L. Wu R.C. and Guo W.W. 2007. Multiple shoot induction from seedling epicotyls and transgenic Citrus plant regeneration containing the green fluorescent protein gene. Botanical Studies. 48: 165 - 171

[30] Duran-Vila N. Ortega V. and Navarro I. 1989. Morphogenesis and tissue cultures of three Citrus species. Plant Cell Tissue and Organ Culture. 16: $123-133$

[31] Duran - Vila N. 1995. Cryoconservation of germplasm of Citrus. In: Bajaj YPS, editor. Biotechnology in Agriculture and Forestry 32. Cryopreservation of Plant Germplasm. Berlin, Germany: Springer - Verlag. $70 \mathrm{~b}-85$

[32] Dutt M. Orbovic V. and Grosser J.W. 2009. Cultivar-dependent gene transfer into Citrus using Agrobacterium. Florida State Horticultural Society. 122: $85-89$

[33] Dutt M. and Grosser J. W. 2010. An embryogenic suspension cell culture system for Agrobacterium-mediated transformation of Citrus. Plant Cell Reports. 29(11): $1251-1260$

[34] Dutt M. Lee D. H. and Grosser J. W. 2010. Bifunctional selection reporte systems for genetic transformation of Citrus: mannoseand kanamycin - based systems. In Vitro Cellular and Developmental Biology Plant. 46(6): 467 - 476

[35] Edriss, M.H. and D.W. Burger, 1984. Micrografting shoot tip culture of Citrus on three trifoliate rootstocks. Scientia Horticulturae. 23: $255-259$

[36] Edriss M.H. and Burger D.W. 1984. In vitro propagation of 'Troyer' citrange from epicotyl segments. Scientia Horticulturae 23: 159 $-162$

[37] Esen A. Soost R.K. .1973. Seed development in Citrus with special reference to $2 \times 4$ crosses. American Journal of Botany. 60:448 $-452$

[38] Engelmann F. Dambier D. and Ollitrault P. 1994. Cryopreservation of embryogenic cell suspensions and calluses of Citrus using a simplified freezing process. Cryo-Letters 15: $53-58$

[39] Fleming G.H. Olivares-Fuster O. Del - Bosco S. Grosser J.W. 2000. An alternative method for the genetic transformation of sweet orange. In Vitro Cell Development. 36(6): 450 - 455

[40] Frost H.B. Cameron J.W. and Soos R.K. 1957. Diversity among nucellar seedling lines of Satsuma mandarin and differences from the parental old line. Hilgardia. 27: $201-222$ 
[41] Garcia - Agustin P. and Primo - Millo E. 1995. Selection of a NaCl tolerant Citrus plant. Plant Cell Reports. 14(5): 314 - 318

[42] Gattuso G. Barreca D. Gargiulli C. 2007. Flavonoid composition of citrusjuices. Molecules 12: $1641-1673$

[43] George E. F. 1993b. Methods of elimination. In E. F. George, M. A. Hall, \& Geet-Jan De Klerk (Eds.), Plant propagation by tissue culture. part I. The technology Westbury. England: Exegetics Ltd. 146 - 151

[44] Gill M.I.S. 1992. Studies on somatic cell and protoplast culture in mandarins. Ph.D. Thesis Punjab Agricultural University. Ludhiana

[45] Gill, M.I.S. Zora Singh Dhillon B.S. and Gosal S.S. 1994. Somatic embryogenesis and plantlet regeneration on calluses derived from seedling explants of Kinnow mandarin (Citrus nobilis Lour. X Citrus deliciosa Tenora). Journal Horticulture Science. 69: 231 - 236

[46] Gill M. I.S. Singh Z. Dhillon B.S. and Gosal S.S. 1995. Somatic embryogenesi and plant regeneration in mandarin (Citrus reticulata Blanco). Scientia Horticulturae 63: $167-174$

[47] Gill S.S. Anjum N.A. Hasanuzzaman M. Gil R. Trivedi D.K. Ahmad I. Pereira E. Tuteja N. 2013. Glutathione and glutathione reductase: a boon in disguise forplant abiotic stress defense operations. Plant Physiology and Biochemistry. 70: 204 - 212

[48] Gmitter F.G. Ling X.B. .1991. Embryogenesis in vitro and nonchimeric tetraploid plant-recovery from underdeveloped Citrus ovules treated with colchicine. Journal of the American Society for Horticultural Science. $116: 317-321$

[49] Gmitter F.G. Ling X.B. Cai C.Y. Grosser J.W. 1991. Colchicineinduced polyploidy in Citrus embryogenic cultures, somatic embryos, and regenerated plantlets. Plant Science. 74:135 - 141

[50] Gmitter F.G. Grosser J.W. and Moore G. A. 1992. Citrus, in biotechnology of perennial fruit crops. Hammerschlag F. A. and Litz R. E. Eds. Pages 335 - 369. CAB International, Wallingford. UK

[51] Goncalves S. and Romano A. 2013. In vitro culture of lavenders (Lavandula spp.) and the production of secondary metabolites. Biotechnology Advances. 31: 166 - 174

[52] Gonzales - Arnao M.T. Ortega J.C. Navarro L. Duran - Vila N., 2003. Cryopreservation of ovules and somatic embryos of Citrus using the encapsulation-dehydration technique. Cryo Letters . 24: 85 - 94

[53] Gonzales - Arnao M.T. Panta A. Roca W.R. Escobar R.H. EngelmannF. 2008 Development and large scale application of cryopreservation techniques for shoot and somatic embryo cultures of tropical crops. Plant Cell Tissue Organ Culture. 92 : 1 - 13 http://dx.doi.org/10.1007/s11240-007-9303-7

[54] Gosslau A. Chen K.Y. Ho C.T. 2014. Anti - inflammatory effects of charac-terized orange peel extracts enriched with bioactive polymethoxyflavones. Food Science and Human Wellness. 3(1): $26-35$

[55] Guo W.W. and Deng X.X. 1998. Somatic hybrid plantlets regeneration between Citrus and its wild relative, Murraya paniculata via protoplast fusion, Plant Cell Reports. 18:297 - 300

[56] Guo W.W. Deng X.X.2001. Wide somatic hybrids of Citrus with its related genera and their potential in genetic improvement. Euphytica. 118:175 - 183

[57] Greno V. Navarro L. and Duran -Vila N. 1988. Influenceof virus and virus-like agents on the development of Citrus buds cultured in vitro. Plant Cell, Tissue and Organ Culture. vol. 15(2): 113 - 124

[58] Grinblat U. 1972. Differentiation of Citrus stem in vitro. Journal of the American Society for Horticultural Science. 97: 599 - 603

[59] Grosser J.W. Gmitter J R F.G. 1990a. Protoplast fusion and Citrus improvement. Plant Breeding. Reviews. 8: 339 - 374

[60] Grosser, J.W. and Gmitter, Jr. F.G. 1990b. Somatic hybridization of Citrus with wild relatives for germplasm enhancement and cultivar development. HortScience. 25:147 - 151

[61] Grosser J.W. Mourao - Fo F.A.A. Gmitter Jr F.G. Louzada E.S. Jiang J. Baergen K. Quiros A. Cabasson C. Schell J.L. Chandler J.L. 1996. Allotetraploid hybrids between Citrus and seven related genera produced by somatic hybridization, Theoritical and Applied Genetics. 92: 577 - 582

[62] Grosser J.W. Gmitter J.R. and Chandler J.L. 1997. Development of improved sweet orange cultivars using tissue culture methods. Florida State Horticultural Society. 110: $13-16$

[63] Grosser J.W. Jiang J. Mourao - Fo F.A.A. Louzada E.S.. Baergen K. Chandler J.L. Gmitter Jr. F.G. 1998. Somatic Hybridization, an integral component of Citrus cultivar improvement: I. Scion Improvement, HortScience. 33:1057 - 1059

[64] Grosser J.W. Chandler J.L. 2000. Somatic hybridisation of high yield, cold hardy and disease resistant parents for Citrus rootstock improvement, The Journal of Horticultural. Science and Biotechnology 75: $641-644$

[65] Grosser J.W. Ollitrault P. and Olivares - Fuster O. 2000. Somatic hybridizatio in Citrus: an effective tool to facilitate variety improvement. In Vitro Cellular \& Developmental Biology. 36: $434-449$

[66] Gutierrez E.M.A. Luth D. and Moore G.A. 1997. Factors affecting Agrobacterim mediated transformation in Citrus and production of sour orange (Citrus aurantium L.) plant expressing the coat protein gene of Citrus tristeza virus. Plant Cell Reports. 16: 745 - 753

[67] Hammschlag F. Ritchie D. Werner D. Hashmil G. Krusberg L. Meyer R. Huettel R. 1995. In vitro selection of disease reistance in fruit trees. Acta Horticultural. 392: $19-26$

[68] Hidaka, T., Yamada, Y. and Shichijo, T. 1981. Plantlet formation from anthers of Citrus aurantium L. Proceedings of the International Society of Citriculture. 1:153-155

[69] Hu J.T. and Kong K.L. 1987. The organogenesis of buds from entire lamina of Citrus sinensis in tissue culture and their anatomical observations. International Journal of Fruit Science. 7: $81-84$

[70] Jaskani M.J. Hassan S. Bashir M.A. Khan I.A 1996. Morphological descriptions of Citrus colchiploids. Proceedings of the International Society of Citriculture. 8:37

[71] Jia - Long Y. Jin - Hu W. Gleave A.P. Morris B.A.M. 1996. Transformation of Citrus embryogenic cells using particle bombardment and production of transgenic embryos. Plant Science. 113(2): $175-183$ 
[72] Kadota M, Niimi Y. 2002. In vitro induction of tetraploid plants from a diploid Japanese pear cultivar (Pyrus pyrifolia N. cn. Hosui). Plant Cell Reports. 21: $282-286$

[73] Kaneyoshi J. Kobayashi S. Nakamura Y. Shigemoto N. and Doi Y. 1994. A simple and efficient gene transfer system of trifoliate orange (Poncirus trifoliata Raf.) Plant Cell Reports. 13: 541 - 545

[74] Kapari - Isaia T. H. Minas G. J. Polykarpou D. Iosephidou E. Arseni S.P. and Kyriakou A. 2002. Shoot-tip grafting in vitro for elimination of viroids and Citrus psorosis virus in the local "Arakapas" mandarin in Cyprus. In Proceedings fifteenth IOCV conference. 417 - 419. Riverside. CA: IOCV

[75] Kapari - Isaia T.H. Kyriakou A. Ioannides I. Papayiannis L. and Minas G. 2007. Sanitation of local Citrus clones and/or varieties in Cyprus. Acta Horticulturae. 741: $301-306$

[76] Kaya E. Souza F. Yilmaz - Gokdogan E. Ceylan M. Jenderek M. 2016. Cryopreservation of Citrus seed via dehydration followed by immersion in liquid nitrogen. Turkish Journal Of Biology . 41: 242 - 248 . http://dx.doi.org/10.3906/biy-1603-92

[77] Khawale R. N. Singh S. K. Garg G. Baranwal V. K. and Ajirlo S. A. 2006. Agrobacterium - mediated genetic transformation of Nagpur mandarin (Citrus reticulata Blanco)," Current Science. 91(12): 1700 - 1705

[78] Kobayashi S. Sakai A. and Oiyama I. 1990. Cryopreservation in liquid nitrogen of cultured navel orange (Citrus sinensis Osb.) nucellar cells and subsequent plant regeneration. Plant Cell, Tissue and Organ Culture. 23:15 - 20

[79] Ladania M.S. 2008. Citrus Fruit Biology, Technology and Evaluation. Elsevier Inc.. Limmaset P. and Cornuet P. 1949. Recherche de virus de la mosaique du Tabac (Marmor Tabaci Holmes) dans les meristemes des plantes infectees. Comptes Rendus Hebdomadaires des Seances de 1Academie des Sciences. 228, 1971 - 1972

[80] Lai C.S. Li S. Chai C.Y. 2007. Inhibitory effect of Citurs 5 - hydroxy - 36,7,8,3, 4 - hexamethoxyflavone on 12 - O tetradecanoylphorbol 13 - acetate iinduced skin inflammation and tumor promotion in mice. Carcinogenesis. 28: 2582 - 2588

[81] Lai C.S. Tsai M.L. Cheng A.C. 2011. Chemoprevention of colonic tumorigenesis by dietary hydroxylated polymethoxyflavones inazoxymethane - treated mice. Molecular Nutrition \& Food Research. 55: 278 - 290

[82] Larkin P.J. and Scowcroft W. 1981. Somaclonal Variation - A Novel Source of Variability from Cell Cultures for Plant Improvement. Theoretical and Applied Genetics. 60: 197 - 214

[83] Li S. Pan M.H. Lo C.Y. 2009. Chemistry and health effects of poly-methoxyflavones and hydroxylated polymethoxyflavones. Journal of Functional Foods. 1: 2 - 12

[84] Li S. Wang H. Guo L. 2014 Chemistry and bioactivity of nobiletin andits metabolites, Journal of Functional Foods. 6: 2 - 10

[85] Li S. Lin Y.C. Ho C.T. 2014. Formulated extract from multiple Citrus peels impairs dendritic cell functions and attenuates allergic contact hypersensitivity. International Immunopharmacol. $20: 12-23$

[86] Lombardo G. Alessandro R. Scialabba A. Sciandra M. De Pasquale F. 2011. Direct organogenesis from cotyledons in cultivars of Citrus clementina Hort. Ex Tan. Am. Journal of Plant Science. 2: 237 - 244

[87] Lopez - Lazaro M. 2002. Flavonoids as anti - cancer agents: structure activity relationship study. Current Medicinal Chemistry. Anti - cancer Agents. 2: $691-714$

[88] Louzada E.S. Jiang J. Baergen K. Quiros A. Cabasson C. Schell J.L., Chandler J.L. 1996 Allotetraploid hybrids between Citrus and seven related genera produced by somatic hybridization, Theoritical and Applied Genetics. 92: 577 - 582

[89] Luth D. and Moore G.A. 1997. Transgenic grapefruit plants obtained by Agrobacterium tumifaciens - mediated transformation. Plant Cell Reports. 57: $219-222$.

[90] Ma N. Lai C.S. Chung C.H. 2014. 5 - Demethyltangeretin is morepotent than tangeretin in inhibiting dimethylbenz(a)anthrene (DMBA)/12-O-tetradecanoylphorbol - 13 - acetate (TPA) induced skin tumorigenesis. Journal of Functional Foods http://dx.doi.org/10.1016/j.jff.2014.08.009

[91] Marin M.L. Duran - Vila, N. 1988. Survival of somatic embryos and recovery of plants of sweet orange [Citrus sinensis (L.) Osb.] after immersion in liquid nitrogen. Plant Cell Tissue and Organ Culture. 14: 51 - 57. http://dx.doi.org/10.1007/BF00029575

[92] Marin M.L. Gogorcena Y. Ortiz J. and Duran - Vila N. 1993. Recovery of whole plants of sweet orange from somatic embryos subjected to freezing thawing treatments. Plant Cell, Tissue and Organ Culture 34:740 - 476

[93] Mendes-da-Gloria F.J. Mourao Filho F.A.A. Camargo L.E.A. Mendes B.M.J. 2000. Caipira sweet orange + Rangpur lime: a somatic hybrid with potential for use as rootstock in the Brazilian Citrus Industry. Genetics and Molecular Biology 23: 661 - 665

[94] Moore G.A. 1985. Factors affecting in vitro embryogenesis from undeveloped ovules of mature Citrus fruit. Journal of the American Society for Horticultural Science. 110: $66-70$

[95] Moore G. A. Jacono C. C. Neidigh J. L. Lawrence S. D. and Cline K. 1992. Agrobacterium - mediated transformation of stem segments and regeneration of transgenec plants. Plant Cell reports. 11: $238-242$

[96] Moore G. A. Jacono C. C. Neidigh J. L. Lawrence S. D. and Cline K. 1993. Transformation in Citrus. In Plant Protoplasts and Genetic Engineering IV.. Bajaj Y. P. S Ed. 23: of Biotechnology in Agriculture and Forestry. 194 - 208. Springer. Berlin Germany

[97] Mukhopadhyay S.J. Raj B.C. Sharma A. Gurung R.K. Nath P.S. 1997. Micropropagation of Darjeeling orange (Citrus reticulata Blanco) by shoot-tip grafting. Journal of Horticultural Science and Biotechnology. 72(3): $493-499$

[98] Mukhtar R. Khan M.M. Fatima B. Abbas M. Shahid A. 2005a. In vitro regeneration and multiple shoots induction in Citrus reticulata (Blanco). International Journal of Agriculture and Biology. 7(3): $414-416$

[99] Mukhtar R. Khan M.M. Rafiq R. Shahid A. Khan F.A. 2005b. In vitro regeneration and somatic embryogenesis in (Citrus aurantifolia and Citrus sinensis). International Journal of Agriculture and Biology. 7(3):518 - 520

[100] Muranaka T. Saito K. 2010. Production of pharmaceuticals by plant tissue cultures. In: Mander, L., Liu, H.W. (Eds.), Comprehensive Natural Products II: Chemistryand Biology. 3: 615 - 628 
[101] Murashige T. and Tucker D.P.H. 1969. Growth factor requirements of Citrus tissue culture. Proceeding of First International Citrus Symposium. 3: 11SS - 1161

[102] Nauer E.M. Roistacher C.N. Carson T.L. and Murashigue T. 1983. In vitro shoot tip grafting to eliminate Citrus viruses and viruslike pathogens produces uniform budlines. Hortscience. 18: $308-309$

[103] Navarro L. Roistacher C. N. and Murashige T. 1975. Improvement of shoot-tip graftingin vitro for virus free Citrus. Journal of the American Society for Horticultural Science. 100: $471-479$

[104] Navarro L. Juarez J. Ballester J.F. Pina J.A. and OrtegaC. 1979. Obtaining nucellar virus - free plants of different Citrus cultivars of the navel group by means of ovule culture in vitro. Anales del Instis Tuto nacional de investigaciones Agrarias. proteccion vegetal. No. 12, 95 - 113 . [Hort. Abst. 51(1): 779]

[105] Navarro L. Roistacher C. N. and MurashigeT. 1976. Effect of size of shoot tips on psorosis - A and exocortis content of navel orange plants obtained by shoot-tip grafting in vitro. In Proceedings of the seventh IOCV conference 194 - 197. Riverside, CA: IOCV

[106] Navarro L. 1988. Application of shoot-tip grafting in vitro to woody species. Acta Horticulturae. 227: 43 - 56

[107] Navarro L. Civerolo E. L. Juarez J. and Garney S. M. 1991 . Improving therapy methods for Citrus germplasm exchange. In Proceedings eleventh IOCV conference . 400 - 408. Riverside. CA: IOCV.

[108] Navarro L. Juarez J. and Pina J. A. 2001. Strategies and problems for the production ofhigh quality nursery Citrus trees worldwide. In Proceedings of the sixteenth world congress of the international society of Citrus Nurserymen Brazil. 1 - 10

[109] Niaz A.C Maken M.N. and Malik S.A. 2004. Native Home, Historical Background and Importance of Citrus Fruitsin Pakistan. Proceedings of the 1st International Conference on Citriculture. University of Agriculture Faisalabad. $48-56$

[110] Nito N. 1996. In : Second International Crop Science Congress. Nov. 17 - 25 , New Delhi, India. Page 40 (Abs)

[111] Nito N. and Iwamasa M. 1990. In vitro plantlet formation from juice vesicle callus of Satsuma (Citrus unshiu Mare.). Plant Cell, Tissue and Organ Culture 20(2): 137 - 140

[112] Notsuka K. Tsuru T. Shiraishi M. 2000. Induced polyploidy in grapes via in vitro chromosome doubling. Journal of the Japanese Society for Horticultural Science. 69: $543-551$

[113] Nuria S. Montserrat P. Carmen F. Pedro M. Luis N. Ricardo F. Leandro P. L. 2012. Transformation of Mexican lime with an intron-hairpin construct expressing untranslatable versions of the genes coding for the three silencing suppressors of Citrus tristeza virus confers complete resistance to the virus. Plant Biotechnology. $1-12$

[114] Oiyama I. 1992. Studies on polyploidy breeding in Citrus with special reference to the production of tetraploid breeding. Bulletin of the Fruit Tree Research Station. 3:68

[115] Olivares - Fuster, O. Asins M.J. Duran -Villa, N. Navarro L. 2000. Cryopreservation of callus, a source of protoplasts for Citrus improvement. J. Hort. Sci. Biotech. 7: 635 - 640. http://dx.doi.org/10.1080/14620316.2000.11511299

[116] Ollitrault P. Dambier D. Luro F. 1996. Somatic hybridization in Citrus, Some new hybrids and cybrids, VIII Congress. International. Society. Citriculture Sun City Resort, South Africa. Page 98

[117] Ollitrault P. Dambier D. Lofty S. Rist D. Mass O. Luro F Frolicher Y. 2000. Citrus germplasm exploitation by somatic hybridization, IXth Congress, International. Society. Citriculture, Orlando - Florida. Page 122

[118] Paudyal K.P. Haq N. 2000. In vitro propagation of pummelo (Citrus grandis L.Osbeck), In Vitro Cellular and Developmental. Biology Plant. 36: $511-516$

[119] Pena L. Cervera M. Juarez J. Navarro A. Pina J.A. and Duran - Vila N. 1995a. Agrobacterium - mediated transformation of sweet orange and regeneration of transgenic plants. Plant Cell Reports. 14: 616 - 619

[120] Pena L. Cervera M. Juarez J. Navarro A. Pina J. and Navarro L. 1997. Genetic transformation of lime (Citrus aurantifolia swing.) factors affecting transformation and regeneration. Plant Cell Reports. 16: $731-737$

[121] Perez R.M. Navarro L. Duran - Vila, N., 1997. Cryopreservation and storage of embryogenic callus cultures of several Citrus species and cultivars. Plant Cell Reports. 17: 44 - 49. http://dx.doi.org/10.1007/s002990050349

[122] Perez - Molphe - Balch E. and Ochoa - Alejo N. 1998. Regeneration of transgenic plants of Mexican lime from Agrobacterium rhizogenes-transformed tissues. Plant Cell Reports. 17(8): 591 - 596

[123] Perveen A. and Qaiser M. 2005. Pollen Flora of Pakistan XLV. Rutaceae. Pakistan Journal of Botany. $37: 495$ - 501

[124] Rangan T.S. Murashige T. and BittersW.P. 1968. In vitro initiation of nucellar embryos in monoembryonic Citrus. HortScience 3(4): $226-227$

[125] Puricelli L. Innocenti G. Delle Monache G. Caniato R. Filippini R. Cappelletti E.M. 2002. In vivo and in vitro production of alkaloids by Haplophyllum patavinum. Natural Product Letters. 16: 95 - 100

[126] Raj Bhansali R. and Arya H.C. 1979. Organogenesis in Citrus limetoides Tanaka (sweet lime) callus culture. Phytomorphology 28: 97- 100

[127] Ralphs M.H. Gardner D.R. 2001. Distribution of norditerpene alkaloids in tall lark-spur plant parts through the growing season. Biochemical Systematics and Ecology . 29: $117-124$

[128] Reforgiato R. G. Russo G. Recupero S. 2005 New promising Citrus triploid hybrids selected from crosses between monoembryonic diploid female and tetraploid male parents. Horticultural Science. 40: 516 - 520

[129] Roistacher C. N. Navarro L. Murashige T. 1976. Recovery of Citrus selections free of several viruses, exocortis viroid and spiroplasma citri by shoot-tip grafting in vitro. Proceeding of 7th International Organization of Citrus Virologists. IOCV, Riverside. $186-193$ 
[130] Sabharwal P.S. 1963. In vitro culture of ovule, nucelli and embryo of Citrus reticulata var. Nagpuri Swingle. In: P. Maheshwari and N.S. Rangaswamy (Editors), Plant Tissue and Organ Culture. Intemational Society of Plant Morphology. Delhi University. Delhi pp $255-274$

[131] Sakai A. Kobayashi S. and Oiyam I. 1990. Cryopreservation of nucellar cells of navel orange (Citrus sinensis var brasiliensis Tanaka) by vitrification. Plant Cell Reports. 9: $30-33$

[132] Sakai A. Kobayashi S. and Oiyam I. 1991. Survival by vitrification of nucellar cells of navel orange (Citrus sinensis var brasiliensis Tanaka) cooled to $196^{\circ} \mathrm{C}$. Plant Physiology. 137: $465-470$

[133] Salmore A.K. Hunter M.D. 2001. Environmental and genotypic influences onisoquinoline alkaloid content in Sanguinaria canadensis. Journal of Chemical Ecology . 27: 1713 - 1747

[134] Santos Filho H.P. Paguio O.R. Coelho Y.S. Medina V.M. 1984. The Citrus variety improvement program in Brazil. Fifth International Citrus Congress. 2: 235 - 237

[135] Sarma C. Borthakur A. Singh S. Mod M.K. Sen P. 2011. Efficient in vitro plant regeneration from cotyledonary explants of Citrus reticulata L. Blanco. 2(6): Annals of Biological Research. 341 - 348

[136] Sauton A. Mouras A. and Lutz A. 1982 . Plant regeneration from Citrus root meristems. Horticultural Science. 57: 227 - 231

[137] Savita Vijay Virk G.S. Nagpal A. 2010. Effect of explant type and different plant growth regulators on callus induction and plantlet regeneration in Citrus jambhiri Lush. Environ. International science technology. 5: 97 - 106

[138] Savita Singh B. Virk G.S. Nagpal A.K. 2011 . An efficient plant regeneration protocol from callus cultures of Citrus jambhiri Lush. Physiology and Molecular Biology of Plants 17(2): 161 - 169

[139] Sidhu O.P. Bel H.M. 1996. Seasonal variation in azaradirachtin in seeds of Azadirachta indica. Current Science. $70: 1084$ - 1085

[140] Sim G.E. Goh C.J. and Loh C.S. 1989 . Micropropagation of Citrus mitis Blanco multiple bud formation from shoot and root explants in the presence of 6-benzylaminopurine. Plant Science 59: $203-210$

[141] Singh I. P. 2001 . Shoot-tip grafting of Mosambi (C. sinensis L. Osbeck) in India. In Proceedings sixteenth world congress of the international society of Citrus Nurserymen Brazil. $128-130$

[142] Singh I. P. 2002. Micropropagation of Citrus - A review. The Agricultural History Review. 23(1): 1 - 13

[143] Singh B. Kaur A. 2011. Comparison of agar and gum karaya as gelling agent for in vitro regeneration of rough lemon (Citrus jambhiri Lush.) plantlets from nodal explants. Journal of Crop Science and Biotechnology. 14(4): 297 - 303

[144] Smetanska I. 2008. Production of secondary metabolites using plant cell cultures. Advances in Biochemical Engineering / Biotechnology. 111: $187-228$

[145] Starrantino A. and Russo F. 1980. Seedlings from undeveloped ovules of ripe fruits of polyembryonic Citrus cultivars. HortScience 15(3): $296-297$

[146] Thorpe T. 2007. History of plant tissue culture. Molecular Biotechnology 37:169- 180

[147] Tripoli E. Guardia M.L. Giammanco S. 2007. Citrus flavonoids: molecular structure, biological activity and nutritional properties. a review. Food Chemistry. 104: 466 - 479

[148] Tusa N. Grosser J.W. Gmitter F.G. 1990. Plant regeneration of 'Valencia' sweet orange, 'Femminello' lemon and the interspecific somatic hybrid following protoplasm fusion. Journal of the American Society for Horticultural Science. 115 (6): 1043 - 1046

[149] Usman M. 2005. Plant propagation and improvement, in Citrus Nursery Raising: Principles and Practices. Mass Publication. Pakistan. $23-66$

[150] Van Le B. Thanh Ha N. Anh Hong L. T. and Tran ThanVan K. 1999. High frequency shoot regeneration from trifoliate orange (Poncirus trifoliata L. Raf.) using the thin cell layer method. Comptes Rendus de l'Academie des Sciences. 322(12): 11056 - 11111

[151] Vardi A. and Galun E. 1989. Isolation and culture of Citrus protoplasts. In: Biotechnology in agriculture and forestry. (Bajaj,Y.P.S.,Ed.). Springer Verlag Berlin Heidelberg. 8:147 - 159

[152] Vardi A. Bleichman S. and Aviv D. 1990. Genetic transformation of Citrus protoplasts and regeneration of transgenic plants. Plant Science. 69: $199-206$

[153] Vishwanath W. And Narayan P. 2015. In Vitro Multiplication of important horticultural Plant Cirus reticulata Blanco. International Journal of Pharmacy and Biological Sciences. 6(1) (B): 1275 - 1280

[154] Wang Z.C. Deng X.X. 2004. Cryopreservation of shoot tips of Citrus using vitrification:effect of reduced form of glutathione. Cryo Letters. 25: $43-50$

[155] Wang L. Wang J. Fang L. 2014. Minireview on the anticancer activities of Citrus peel polymethoxyflavones related to angiogenesis and others. BioMed Research International 4539721 - 10 Article ID

[156] Yaacob J.S. Mahmad N. Taha R.M. Mohamed N. Yussof A.I.M. Saleh A. 2014. Optimization of culture conditions (sucrose, pH, and photoperiod) for in vitro regeneration and early detection of somaclonal variation in ginger lime (Citrus assamensis). The Scientific World Journal ., Article ID 262710. 1 - 9

[157] Yang L. and Hu C. 2011. Transformation of sweet orange [Citrus sinensis (L.) Osbeck] with pthA-nls for acquiring resistance to Citrus canker disease. Plant Mol Biol. 75(1): 11 - 23

[158] Yao J.L. Wu J.H. Gleavea A.P. and Morris B.A.M. 1996. Transformation of Citrus embryogenic cells using particle bombardment of transgenic embryos. Plant Science. 113: 175 - 183

[159] Yuan G. Shui - Gen L.i. Xiao - Fen F.. and Zhen - Hong S. 2016. Application of Somatic Embryogenesis in Woody Plants. Frontiers in Plant Science. 7: 938. 